\title{
Jerzy Tokarski
}

\section{Rozeznanie temperamentu a efektywność procesu mediacji}

Mediator, strona A, strona $\mathrm{B}$, czasem również uczestnik A, uczestnik B itd., kilkadziesiąt minut, stanowiska, oczekiwania, historie, rany, emocje, temperamenty, osobowości, charaktery, niezaspokojone potrzeby. Równanie $\mathrm{z}$ wieloma niewiadomymi oraz $\mathrm{z}$ wieloma rozwiązaniami, nieskończenie wieloma. Czy jest możliwa optymalizacja procesu mediacji poprzez pogłębienie wiedzy o cechach endogennych osobowości, jaką jest temperament ${ }^{1}$ ? Jedną z głównych kompetencji mediatora jest umiejętność zadawania pytań i pozytywnego przeformułowywania stanowisk. Czy rozeznanie bieżącego stanu charakteru lub osobowości stron poprzez zbliżenie się do rdzenia ich charakteru lub osobowości - czyli do pierwotnego temperamentu - jest okolicznością ułatwiającą formułowanie odpowiednich pytań i skutecznych przeformułowań?

W procesie mediacji dobre pytanie warte jest więcej niż wiele mądrych odpowiedzi. Pytanie jest dobre, kiedy przebija „twardy pancerz” stron, głęboko ukrytych w swoich mechanizmach obronnych lub zostawia na tym pancerzu choć drobną ryskę. Czas i ta drobna ryska mogą zdziałać cuda. Tych efektów, rozłożonych w czasie, sam mediator może już nie zauważyć, ale może zauważyć grymas bólu na twarzy strony, kiedy pytanie zarysuje np. „jej nienaganną opinię o sobie samym”. Mediacja nie powinna być usługą ocenianą w systemie akordowym. Nie papier, zapisany porozumieniem i podpisany przez strony, ale wewnętrzne przekonanie strony mediacji - nie jestem nieomylna, inni mają prawo do swojego zdania, nie jestem sędzią ani oskarżonym, ja również mam prawo do własnego zdania, nie jestem „pępkiem świata” - może być rzeczywistym sukcesem mediacji formalnie zakończonej

1 Por. J. Strelau, Psychologia temperamentu, Wydawnictwo Naukowe PWN, Warszawa 2012, s. 52. 
bez porozumienia. W procesie mediacji poszukujemy prawdy spoczywającej $\mathrm{w}$ faktach, których odmienna interpretacja doprowadziła strony do pokoju mediatora. Fakty i przeszłość to niewzruszona podstawa, mediator może jedynie zwrócić uwagę stron na różnice w ocenie tych faktów. Strony mają swój ogląd przeszłości oraz pogląd na teraźniejszość i plany na przyszłość. Mają swoje stanowiska. Skąd się one wzięły? Dlaczego są różne? Dlaczego nie są w stanie samodzielnie rozwiązać konfliktu wywołanego tymi różnicami?

Zastanawiając się nad pytaniem o różnice w ocenie tych samych faktów, poszukujemy tego, co może je połączyć - poprzez próbę ukazania stabilnego, obiektywnego fundamentu, na którym strony zbudowały swoje różne opinie w ocenie takich samych faktów. Część wspólna jest zawsze bezpiecznym obszarem przeformułowywania stanowisk skonfliktowanych stron. Jak zbliżyć się do części wspólnej, łączącej dwie „góry lodowe” dryfujące na wzburzonym oceanie uczuć, i nie zostać zmiażdżonym przez potężną siłę ich niekontrolowanych kolizji? Gdzie mediator może odnaleźć coś stałego, co zakotwiczy te dryfujące podmioty, coś, co pomoże ustabilizować ich interakcje?

Ocena, jaką każdy człowiek formułuje instynktownie, jest uwarunkowana wieloma czynnikami zewnętrznymi. Są to: okoliczności rodzinne, środowiskowe, sytuacja gospodarcza, polityczna, aktualnie dominująca ideologia „głównego nurtu”, kontekst rodziny pochodzenia stron, ich dyspozycje wynikające z wiedzy i doświadczenia. Można by wymieniać jeszcze dalej, jednak te czynniki zewnętrzne są raczej odkryte dla stron, są do stron przypisane, pozostają również $\mathrm{w}$ zasięgu uważnej percepcji mediatora. Te niewiadome mediator może jakoś wstępnie przybliżać, wchodząc w relację ze stronami, wykorzystywać do przeformułowań praktycznie od samego początku procesu. Poza czynnikami zewnętrznymi są też wewnętrzne, które determinują indywidualną ocenę faktów przez każdego z uczestników konfliktu. Czy te zmienne mediator również może jakoś uprościć, spowodować, że skomplikowane równanie stanie się prostym wyrażeniem algebraicznym? Zdecydowanie tak. Stałą, która ma istotny wpływ na formułowane opinie, jest temperament. Czyli koniec tematu? Nie, dopiero początek! Rodzą się bowiem kolejne pytania: Co to jest temperament? Ile ich jest? Co ma wspólnego z osobowością? Jak w tym kontekście zdefiniować charakter? 


\section{Definicja temperamentu}

W każdej rozmowie warunkiem koniecznym efektywnej komunikacji jest wspólny język. Dotyczy to również względnej zgody co do znaczenia używanych przez rozmówców terminów. Bez zdefiniowania znaczenia terminów, takich jak: miłość, wierność, odpowiedzialność, dobro dzieci, potrzeba, emocje, moralność, przynajmniej na poziomie systemu, w którym funkcjonują dane osoby (strony mediacji), wcześniej lub później dojdzie między nimi do konfliktów. Kiedy mówimy „temperament”, „osobowość”, „charakter”, możemy mieć bardzo różne wyobrażenie, o czym właściwie mówimy. Aby mediator mógł skorzystać z wiedzy, jak świadomość temperamentu może przysłużyć się w optymalizacji procesu dochodzenia do porozumienia stron konfliktu, powinien wiedzieć, co to jest temperament. Myślę tutaj o wiedzy zobiektywizowanej w świetle wyników pracy badaczy tej sfery ludzkiej psychiki.

Definicję temperamentu rozpocznę od przeglądu źródeł naukowych, które, w ramach psychologii ogólnej, skupiają się nad tą częścią natury człowieka. Najstarszą, klasyczną klasyfikacją, jest klasyfikacja czterech temperamentów, pochodząca od dwóch lekarzy: Hipokratesa (460-377 rok p.n.e.) i Galena (130-200 rok n.e.). Nawiązuje ona do czterech żywiołów kosmosu (powietrze, woda, ogień, ziemia), które mają odbicie w cieczach znajdujących się w ciele ludzkim (krew, flegma, żółć żółta, żółć czarna), które z kolei wyrażają się odpowiednim usposobieniem (lekkomyślność, lenistwo, gwaltowność, smutek). Korzenie klasyfikacji Hipokratesa tkwią w większości współczesnych teorii i analiz. Potwierdza to jej uniwersalność, trafność co do kierunku analizy, jak również ponadczasowy charakter tych obserwacji.

Punktem wyjścia tej koncepcji był pogląd Empedoklesa z Akragas (V wiek p.n.e.) o czterech żywiołach, które - mieszane przez miłość i nienawiść tworzą rozmaitość rzeczy. Hipokrates wyprowadza z tego cztery soki organizmu. Optymalny stosunek między tymi sokami ma być źródłem zdrowia. Hipokrates nie wprowadza jeszcze powiązania pomiędzy proporcjami soków w organizmie a właściwościami zachowania. Wiąże je z chorobami charakterystycznymi dla czterech pór roku. Galen wykorzystał Hipokratesową koncepcję i stworzył pierwszą typologię temperamentów (łac. temperare - mieszać, kombinować we właściwych proporcjach). Wyróżnił i opisał dziewięć temperamentów, cztery główne - zależne od dominacji głównych soków, cztery dalsze - zależne od kombinacji par tych soków, oraz dziewiąty 
(temperament idealny), który jest równomiernym wymieszaniem tych czterech elementów. Cztery pierwotne typy temperamentów Galen nazwał w zależności od przewagi któregoś z soków w organizmie i przypisał im wiodące humory (zachowania). Ta koncepcja, wiążąca rodzaj temperamentu z przewagą określonych soków w organizmie, znalazła częściowo poparcie w badaniach nad fizjologicznymi podstawami temperamentu. Wykazano, że niektóre cechy temperamentu, zwłaszcza wiążące się z emocjami, mają związek z funkcjonowaniem układu endokrynnego (hormonalnego) ${ }^{2}$.

Tabela 1. Typologia temperamentu wg Hipokratesa i Galena ${ }^{3}$

\begin{tabular}{|c|c|c|c|}
\hline WODA & POWIETRZE & OGIEŃ & ZIEMIA \\
\hline FLEGMA & KREW & ŻóŁĆ ŻóŁTA & ŻÓŁĆ CZARNA \\
\hline łac. phlegma & łac. sanguis & łac. chole & łac. melas chole \\
\hline $\begin{array}{l}\text { głowa } \\
\text { zima }\end{array}$ & $\begin{array}{c}\text { serce } \\
\text { wiosna }\end{array}$ & $\begin{array}{c}\text { wątroba } \\
\text { lato }\end{array}$ & $\begin{array}{l}\text { głowa } \\
\text { zima }\end{array}$ \\
\hline LENISTWO & $\begin{array}{l}\text { LEKKOMYŚL- } \\
\text { NOŚĆ }\end{array}$ & $\begin{array}{l}\text { GWAKTOẂ } \\
\text { NOŚĆ }\end{array}$ & SMUTEK \\
\hline FLEGMATYK & SANGWINIK & CHOLERYK & MELANCHOLIK \\
\hline
\end{tabular}

Wśród bardziej współczesnych badaczy tego tematu wymienię chronologicznie następujące postaci: Immanuel Kant (1724-1804), Wilhelm Wundt

2 J. Strelau, Psychologia temperamentu, Wydawnictwo Naukowe PWN, Warszawa 2012, s. 17.

3 Opracowanie własne na podstawie: J. Tarnowski, Z tajników naszego „Ja”, Księgarnia św. Wojciecha, Poznań 1987. 
(1832-1920), Iwan Pawłow (1849-1936), Carl Gustav Jung (1875-1961), Rene Le Senne (1882-954), Ernest Kretschmer (1888-1964), William Hubert Sheldon (1898-1977) Hans Eysenck (1916-1997), Paul MacLean (1913-2007). Każdy z tych badaczy wniósł wkład w zrozumienie ludzkiego temperamentu, często używając różnej terminologii na określenie tych samych lub podobnych cech i zjawisk. Zachęcam do głębszego zapoznania się z tymi teoriami.

We współczesnej literaturze z zakresu motywacji, rozwoju, manipulacji, jak również w ofercie szkoleniowej spotkać można wiele teorii i prostych narzędzi, wykorzystywanych w zarządzaniu „kapitałem” ludzkim, w marketingu, segmentacji konsumentów, kreowaniu potrzeb (np. cztery kolory osobowości, trzy kolory mózgu), które - zakładając redukcyjną wizję człowieka - sprowadzają jego reakcje do zachowań instynktowych. Dla mediatora ten poziom znajomości zagadnień związanych $\mathrm{z}$ temperamentem $\mathrm{i}$ jego typologią jest zdecydowanie zbyt ubogi. Uważam, że studiowanie tego zakresu wiedzy mediator powinien przerwać dopiero w momencie, gdy uzyska dogłębną świadomość, na poziomie zrozumienia, że każdy człowiek jest indywidualną i niepowtarzalną jednostką, obdarowaną wyjątkowym temperamentem. Temperament ten uposaża każdego indywidualnie - na początku jego egzystencji - w to, co konieczne do osiągnięcia dojrzałej osobowości.

Jak zbliżyć się do tego poziomu kompetencji, by następnie wykorzystać ten zasób do próby odkłamania (zmanipulowanego) subiektywnego obrazu świata, jaki często prezentują strony mediacji, wejść w postawę bezstronności, koniecznej w mediacji, dojść do rozumowej (z szacunkiem i uważnością na emocje) oceny faktów? Jak ukierunkować strony mediacji do bardziej świadomego wzięcia za siebie odpowiedzialności? Proponuję na wstępie wybrać dorobek jednego z wymienionych badaczy i pogłębić wiedzę w tym zakresie. To pierwszy krok. Jeżeli nie będzie ostatnim - spodziewajmy się owoców. Moim zdaniem bardzo praktyczna i dobrze opisana jest typologia temperamentu zaproponowana przez szkołę Le Senne’a, którą szczegółowo opracował Janusz Tarnowski w pracy pt. Z tajników naszego „Ja”.

Klasyfikacja dokonana przez francuskiego filozofa i psychologa Rene Le Senne'a oparła się o badania holenderskiego uniwersytetu w Griningen, które przeprowadził Gerard Heymans (psycholog i filozof, zmarł w 1930 roku) oraz Enno Wersma (psychiatra, zmarł w 1940 roku). Typologia ta czerpie z doświadczeń wcześniejszych, opiera się na analizie historycznej życiorysów 110 sławnych osób oraz na badaniu ankietowym 2523 przypadków 
współczesnych badaczom. Badania empiryczne Heymansa i Wiersmy objęły całokształt zachowań i cech psychicznych człowieka. Wyodrębniono trzy podstawowe wymiary temperamentu: aktywność, emocjonalność, funkcję pierwotną (prymalność) i wtórną (sekundalność) $)^{4}$.

Emocjonalność (E lub nE) jest dyspozycją do ulegania silnym poruszeniom psychicznym, nawet wskutek stosunkowo niewielkiej podniety, nie występuje nigdy bez powiązania z innymi dyspozycjami. Nieemocjonalnść nie występuje jako brak emocji, a jedynie jako pewien spokojny ogląd sytuacji. Nikt nie może wyłączyć emocji, można je jedynie zamrozić tylko na jakiś czas.

Tabela 2. Typologia temperamentów wg Heymansa i Wiersmy ${ }^{5}$

\begin{tabular}{|c|c|c|c|}
\hline Emocjonalność & Aktywność & Oddźwięk psychiczny & Typ temperamentu \\
\hline - & - & $\mathrm{P}$ & amorficzny \\
\hline - & - & S & apatyczny \\
\hline+ & - & $\mathrm{P}$ & nerwowy \\
\hline+ & - & S & sentymentalny \\
\hline - & + & $\mathrm{P}$ & sangwinistyczny \\
\hline - & + & $\mathrm{S}$ & flegmatyczny \\
\hline+ & + & $\mathrm{P}$ & choleryczny \\
\hline+ & + & S & pasjonujący (się) \\
\hline \multicolumn{2}{|c|}{$\begin{array}{l}\text { + duże nasycenie danej cechy } \\
\text { - małe nasvcenie danej cechy }\end{array}$} & $\begin{array}{l}\mathrm{P} \text { - prymalny } \\
\mathrm{S} \text { - sekundalny }\end{array}$ & \\
\hline
\end{tabular}

Aktywność (A lub nA) jest dyspozycją do spontanicznego działania mimo przeszkód. Aktywnym nazywamy człowieka, który wobec pojawiającej się

4 Por. J. Tarnowski, Z tajników naszego „Ja”, dz. cyt., s. 3 o.

5 Opracowanie własne na podstawie: J. Strelau, Psychologia temperamentu, dz. cyt., s 23. 
przeszkody wzmaga swoje działanie w kierunku utrudnianym przez przeszkodę. Nieaktywnemu zaś przeszkoda odbiera odwagę.

Oddźwięk psychiczny: prymalność (P) lub sekundalność (S) to dyspozycja świadomości do szybkiego lub powolnego, krótkiego lub długiego przechowywania reakcji na doznane podniety. Prymalny jest ten, u kogo dominuje reakcja szybka i krótka. Osobę o reakcji powolnej lub opóźnionej, ale trwalszej, nazwiemy sekundalną.

Biorąc pod uwagę wszystkie możliwe kombinacje tych trzech wymiarów (dyspozycji) temperamentu, z których każda ma dwa bieguny, skonstruowano typologię temperamentów, opisaną schematycznie w tabeli 2.

Le Senna rozwinął tę typologię o kolejne dyspozycje i wprowadził czwartą dyspozycję podstawową: Zakres pola świadomości - w uproszczeniu można ją opisać jako podzielność uwagi i zdolność do jednoczesnego obejmowania uwagą wielu wrażeń lub skupianie się na wybranych i odrzuceniu innych. Każdy, wymieniony w tabeli typ, może być wąski (nL) lub szeroki (L).

Wówczas otrzymujemy już 16 typów. Le Senne wprowadził też dyspozycje uzupełniające:

- Biegunowość - wojowniczość (M - Mars) lub ugodowość (V - Venus).

- Zachłanność (z franc. avidite) - (Av lub nAv) - dyspozycja do wprowadzania świata zewnętrznego w swoje wnętrze i przekształcania go na swój sposób. Pragnienie posiadania wartości materialnych lub niematerialnych, zdobywanie i utrzymywanie.

- Upodobania zmysłowe (z franc. interets sensoriels) - (Is lub nIs) - dyspozycja do odczuwania przyjemności w doznaniach zmysłowych, niezależnie od ich przydatności biologicznej, np. jedzenie.

- Tkliwość - (z franc. tendresse) - (T lub nT) - blisko tutaj do empatii, jest to utożsamianie własnych myśli przeżyć z myślami i przeżyciami innych ludzi.

- Towarzyskość versus Separatywność - (J - Jupiter lub S - Saturn) dyspozycja do łączności z osobami z otoczenia.

- Pasja intelektualna - (Is lub nIs) - skłonność do pogłębionej analizy rzeczywistości.

Poznanie dyspozycji uzupełniających jest bardzo ważne. Określenie natężenia dyspozycji podstawowych nie mówi wszystkiego o typie temperamentu. Etykietowanie ludzi jako: choleryków, sangwiników, nerwowców itd., jest niebezpiecznym uproszczeniem i może być przejawem lenistwa 
intelektualnego osoby badającej. Dopiero sięgnięcie do dyspozycji uzupełniających pozwala, w pewnym stopniu, zdać sobie sprawę z bogactwa psychiki człowieka poddanego badaniu. Zdarza się, że jedna lub więcej dyspozycji podstawowych danej osoby znajduje się w pobliżu przeciętnej, co powoduje kłopot z zaliczeniem jej do takiego czy innego typu. Gdy wówczas zbadamy dyspozycje uzupełniające, okazać się może, że któraś z nich jest bardzo intensywna. W takim przypadku bez wykrycia dyspozycji uzupełniających obraz badanego temperamentu może być bardzo niedokładny. Dyspozycje podstawowe E, A, P/S, L dla pewnej liczby osób mogą właściwie mieć wartość drugorzędną, właśnie uzupełniającą, z racji na niską lub średnią swą intensywność. Natomiast niektóre dyspozycje, zwane uzupełniającymi, dzięki silnemu natężeniu mogą u tych osób przesunąć się na pierwszy plan i spełniać rolę dyspozycji podstawowych. Dzięki pracy Le Senne’a otrzymujemy zwielokrotnienie dyspozycji poddawanych analizie.

Tabela 3. Zestawienie typologii temperamentów zastosowanych przez wybranych badaczy $^{6}$

\begin{tabular}{|c|c|c|c|c|}
\hline $\begin{array}{l}\text { Hipokrates } \\
\text { Galen } \\
\text { (klasyczny } \\
\text { podzial) }\end{array}$ & $\begin{array}{c}\text { Joung } \\
\text { (splaszczony } \\
\text { do świadomo- } \\
\text { ści i zachowań) }\end{array}$ & $\begin{array}{c}\text { Kant } \\
\text { Wundt } \\
\text { (4 kolory) }\end{array}$ & $\begin{array}{l}\text { Heymans } \\
\text { Wiersma } \\
\text { Le Senne }\end{array}$ & $\begin{array}{l}\text { Kod literowy } \\
\text { wg Le Senne'a }\end{array}$ \\
\hline \multirow{2}{*}{ Melancholik } & \multirow{4}{*}{ Introwertyk } & \multirow{2}{*}{ Melancholik } & Sentymentalny & EnAS \\
\hline & & & Flegmatyk & $\mathrm{nEAS}$ \\
\hline \multirow{2}{*}{ Flegmatyk } & & \multirow{2}{*}{ Flegmatyk } & Amorfik & nEnAP \\
\hline & & & Apatyk & $\mathrm{nEnAS}$ \\
\hline \multirow{2}{*}{ Sangwinik } & \multirow{4}{*}{ Ekstrawertyk } & \multirow{2}{*}{ Sangwinik } & Nerwowiec & EnAP \\
\hline & & & Sangwinik & $\mathrm{nE}$ A P \\
\hline \multirow{2}{*}{ Choleryk } & & \multirow{2}{*}{ Choleryk } & Pasjonat & EA S \\
\hline & & & Choleryk & E A P \\
\hline
\end{tabular}

W kwestionariuszu analitycznym Bergera ${ }^{7}$ możemy określić intensywność dziewięciu dyspozycji (a nie jest to katalog zamknięty), co pozwala na otrzymanie aż 512 typów temperamentu, tylko z zestawienia możliwych

6 Opracowanie własne na podstawie: J. Tarnowski, Z tajników naszego "JA", dz. cyt.

7 Por. G. Berger, Traite pratique d'analyse du caractere, Paris 1958, cyt. za: J. Tarnowski, Z tajników naszego "JA", dz. cyt., s. 320. 
kombinacji cech. Kiedy uświadomimy sobie, że każda z tych cech może mieć różną intensywność, to możliwe kombinacje przekraczają już proste obliczenia. I w tym momencie właściwe jest spostrzeżenie, iż rzeczywistość ludzkiej osobowości jest skomplikowana, dlatego nie można jej zamknąć w formułki. Typologia Le Senne’a ma też swoje wady. Jedną z nich jest brak jednoznaczności nazw typów w stosunku do typologii wcześniejszych. Próbę usystematyzowania terminologii stosowanej przez kilku badaczy przedstawia tabela 3.

Proponuję korzystanie $\mathrm{z}$ opisu formuły temperamentu przy wykorzystaniu symboli literowych, co pozwala na ograniczenie stygmatyzujących efektów wywołanych wstępnym określeniem głównych dyspozycji temperamentu i naklejeniem „etykiety” na jedyną i niepowtarzalną - poddaną analizie - osobę.

Podsumujmy: temperamentu nie wybieramy, podobnie jak nie wybieramy płci - rodzimy się z tymi cechami. Większość badaczy temperamentu zgadza się co do tego, że:

- temperament to cechy zachowania, którymi ludzie się różnią. Różnice te opisuje się za pomocą takich pojęć jak: dyspozycja, cecha, właściwość, czynnik, wymiar, typ, kategoria. Wielu badaczy używa tych terminów zamiennie;

- w porównaniu z innymi zjawiskami temperament charakteryzuje się względną stałością w ciągu życia i spójnością międzysytuacyjną. Nie należy jednak rozumieć terminów „stałość” i „spójność” dosłownie. Chodzi jedynie o to, że temperament, w porównaniu z innymi właściwościami zachowania, odznacza się największą stałością i międzysytuacyjną spójnością;

- temperament ma podłoże biologiczne. Panują jednak wśród badaczy różne opinie co do rodzaju i liczby struktur anatomicznych i mechanizmów fizjologicznych stanowiących podłoże biologiczne temperamentu;

- pojęcie temperamentu odnosi się przede wszystkim do formalnej charakterystyki zachowania lub reakcji - do takich parametrów jak: intensywność, energia, siła, szybkość, tempo, zmienność, ruchliwość itp. W niektórych koncepcjach cechy te ograniczają się wyłącznie do sfery emocji, w innych zaś obejmują one wszystkie zachowania ${ }^{8}$.

8 Por. J. Strelau, Psychologia temperamentu, dz. cyt., s. 48. 
Profesor Jan Strelau proponuje następującą definicję temperamentu: Temperament odnosi się do względnie stałych cech osobowości występujących u człowieka od wczesnego dzieciństwa i mających swoje odpowiedniki $\mathrm{w}$ świecie zwierząt. Będąc pierwotnie zdeterminowany przez wrodzone mechanizmy neurobiochemiczne, temperament podlega powolnym zmianom spowodowanym procesem dojrzewania oraz specyficznym dla jednostki oddziaływaniem między genotypem a środowiskiem ${ }^{9}$.

W tej definicji zawiera się cała dotychczasowa wiedza na ten temat, co pozwala na prowadzenie dyskusji w każdym środowisku. Konsumuje ona wcześniejsze badania i teorie. Jeżeli w punkcie wyjścia tej dyskusji przyjmiemy też prawdę o człowieku jako koronie stworzenia, możemy w piękny sposób poprowadzić rozważania nad faktami, bez ciężaru oceny osoby, skupiając się jedynie na jej zachowaniach godnych uznania lub potępienia.

\section{Rozeznawanie temperamentu}

Jak wiedzę o temperamencie zdyskontować w procesie mediacji? Jak zbliżyć się do przekonania, że wykorzystaliśmy ją dla optymalizacji procesu i maksymalizacji efektu? Efektu rozumianego jako zbliżenie do trwałego porozumienia stron w kwestii, która jest źródłem konfliktu, i złagodzenie wywołanego tym konfliktem kryzysu. Żaden mediator nie będzie w stanie wykorzystać wiedzy o temperamentach, jeżeli nie określi najpierw swojego miejsca na tej nieograniczonej palecie obdarowań. Jako wstęp do autoanalizy i zachętę do skorzystania z innych narzędzi analitycznych, samoobserwacji, analizy cech morfologicznych, przedstawię kwestionariusz analityczny Mucchielli'ego-Verdiera ${ }^{10}$, skrócony do odpowiedzi na zestaw 15 pytań, dla których określamy, czy postawa przedstawiona w pytaniu:

- uznawana jest całkowicie za moją - wówczas zapisujemy 2 punkty,

- uznana częściowo za moją - zapisujemy wówczas 1 punkt,

- lub zupełnie się z nią nie zgadzam - zapisujemy o punktów.

Pytania i punktacja są tak dobrane, aby wartość punktowa nie sugerowała badanemu siły dyspozycji.

9 Por. J. Strelau, Psychologia temperamentu, dz. cyt., s. 49.

10 Por. R. Mucchhielli, Psychologie pratique des eleves de 7 a 12 ans, Paris 1958, cyt. za: J. Tarnowski, Z tajników naszego „JA”, dz. cyt., s. 337. 
Tabela 4. Pytanie kwestionariuszowe pomocne do określenia trzech dyspozycji temperamentu"

\begin{tabular}{|c|c|c|c|}
\hline $\mathrm{Nr}$ & Pytanie & $\begin{array}{l}\text { Punkty } \\
{[2-1-0]}\end{array}$ & $\begin{array}{l}\text { Suma } \\
\text { punktów }\end{array}$ \\
\hline 1 & $\begin{array}{l}\text { Czy denerwujesz się szybko, gdy jakaś rzecz nie idzie ci tak, } \\
\text { jakbyś sobie tego życzył? }\end{array}$ & & \\
\hline 2 & $\begin{array}{l}\text { Czy wzruszasz się opowiadaniem, książką, filmem lub sztuką } \\
\text { tak jak rzeczywistością? }\end{array}$ & & \\
\hline 3 & $\begin{array}{l}\text { Czy wpadasz szybko w gniew (nawet jeżeli to nie jest } \\
\text { widoczne)? }\end{array}$ & & \\
\hline 4 & $\begin{array}{l}\text { Czy twój humor jest zmienny (czy bywasz niekiedy w do- } \\
\text { brym humorze, a kiedy indziej w bardzo złym) bez wyraźnej } \\
\text { przyczyny? }\end{array}$ & & \\
\hline 5 & $\begin{array}{l}\text { Czy doznajesz tremy przed egzaminem, odpowiedzią, wystą- } \\
\text { pieniem publicznym? }\end{array}$ & & \\
\hline 6 & Czy zabierasz się powoli do jakiejś pracy (zajęcia)? & & \\
\hline 7 & Czy szybko męczysz się lub nudzisz jakąś pracą? & & \\
\hline 8 & Czy mając czas wolny, szukasz raczej rozrywek niż zajęcia? & & \\
\hline 9 & $\begin{array}{l}\text { Czy po dostaniu złego stopnia lub po niepowodzeniu pracujesz } \\
\text { mniej lub gorzej? }\end{array}$ & & \\
\hline 10 & Czy wolisz nie przemęczać się zbyt trudną pracą? & & \\
\hline 11 & $\begin{array}{l}\text { Czy trudno ci zapomnieć doznanych uraz, porażek, } \\
\text { przykrości? }\end{array}$ & & \\
\hline 12 & $\begin{array}{l}\text { Czy przywiązujesz znaczną wagę do twych drobnych } \\
\text { przyzwyczajeń? }\end{array}$ & & \\
\hline 13 & $\begin{array}{l}\text { Czy myślisz z góry o tym, co ma nastąpić, czy pragniesz do } \\
\text { tego przygotować się w miarę możliwości? }\end{array}$ & & \\
\hline 14 & Czy lubisz wspominać dawne wrażenia, przeżycia? & & \\
\hline 15 & $\begin{array}{l}\text { Czy lubisz udawać się na wakacje w te same miejsca? Czy przy- } \\
\text { zwyczajasz się do miejsc, osób, warunków? }\end{array}$ & & \\
\hline
\end{tabular}

11 Opracowanie na podstawie: J. Tarnowski, Z tajników naszego „JA”, dz. cyt., Poznań 1987. 
Po zakończeniu odpowiedzi obliczamy sumę punktów otrzymanych na pytania przyporządkowane do poszczególnych dyspozycji i zapisujemy je w odpowiednim polu, poniższej tabeli. Wyniki na poziomie 5 punktów wymagają szczególnego namysłu, mogą świadczyć o neutralnym oddziaływaniu cechy na temperament badanego. Wyniki: 6 i powyżej 6 punktów wpisujemy bezpośrednio do tabeli 5. Dla wyników: od o do 5 wykonujemy odejmowanie: 10 minus otrzymany wynik, dopiero tę różnicę wpisujemy do tabeli.

Tabela 5. Określenie wyników badania kwestionariuszowego ${ }^{12}$

\begin{tabular}{|c|c|c|c|c|}
\hline Numery pytań & Suma punktów & Wynik & Cecha & Opis \\
\hline \multirow{2}{*}{$1-5$} & $\begin{array}{l}10 \text { minus suma } \\
\text { uzyskana }\end{array}$ & & $\mathrm{nE}$ & \multirow{2}{*}{ Emocjonalność } \\
\hline & $6-10$ & & $\mathrm{E}$ & \\
\hline \multirow{2}{*}{$6-10$} & $\begin{array}{c}10 \text { minus suma } \\
\text { uzyskana }\end{array}$ & & A & \multirow{2}{*}{ Aktywność } \\
\hline & $6-10$ & & $\mathrm{nA}$ & \\
\hline \multirow{2}{*}{$11-15$} & $\begin{array}{c}10 \text { minus suma } \\
\text { uzyskana }\end{array}$ & & $\mathrm{P}$ & \multirow{2}{*}{ Oddźwiękowość } \\
\hline & $6-10$ & & $\mathrm{~S}$ & \\
\hline
\end{tabular}

Po spisaniu symboli cech, dla których przyporządkowaliśmy nasz wynik, otrzymujemy własną podstawową formułę typu temperamentu, ograniczoną do trzech dyspozycji. Wartości liczbowe wskazują na siłę cechy w obszarze badanej dyspozycji. Po określeniu formuły temperamentu możemy zapoznać się z skrótowym opisem głównych cech charakterystycznych dla ośmiu „czystych temperamentów”, pamiętając nade wszystko, że w życiu postaci czyste i modelowe nie występują ${ }^{13}$. Jest to jedynie ukierunkowanie na drodze ku poznaniu własnego rdzenia osobowości (temperamentu).

12 Opracowanie na podstawie: J. Tarnowski, Z tajników naszego „JA”, dz. cyt.

13 Opis cech na podstawie: J. Tarnowski, Z tajników naszego „JA”, dz. cyt. 
Formuła EnAP - cechy charakterystyczne

Odznacza się usposobieniem krańcowo-zmiennym, w krótkim czasie przechodzi od łez do śmiechu. Spragniony uczuć, ale niestały w swoich sympatiach, wciąż poszukuje nowych wrażeń. Odczuwa potrzebę upiększania rzeczywistości, co prowadzi go do fikcji poetyckiej lub do kłamstwa. Impulsywny, ocenia ludzi zależnie od tego, czy z nim sympatyzują, czy też nie; ma nieraz gust do okropności i makabry. Potrzebuje podniet, by wyrwać się z bezczynności i nudy. Niezdolny do pracy systematycznej, oddaje się zajęciom ulubionym, a zaniedbuje obowiązkowe. Chce wzbudzić podziw i zwracać na siebie uwagę. Szybko się zapala i prędko gaśnie: typowy „słomiany ogień”. Po doznanych niepowodzeniach daje się łatwo pocieszyć. Snuje wielkie plany, których nie urzeczywistnia. Lubi życie towarzyskie, odznacza się błyskotliwą inteligencją. Nie umie oprzeć się pokusie, ale szczerze żałuje swoich upadków. Główną jego wartością jest piękno albo rozrywka.

Formuła nEAS - cechy charakterystyczne

Jest zrównoważony, obiektywny, szanujący zasady i punktualny. Mimo chłodu i pozornej nieczułości umie pomagać potrzebującym. Cierpliwy, odważny, wytrwały i naturalny, po prostu nie umie udawać. Obdarzony jest zdolnością jasnego i treściwego wypowiadania się, chociaż może niekiedy nużyć słuchaczy. Uzdolniony do matematyki i nauk ścisłych, posiada umiejętność abstrakcji. Ma wybitne poczucie humoru, na co nie wydaje się wskazywać jego na ogół poważny wygląd. Pracuje systematycznie, choć powoli, nie znosi pośpiechu. Wierny swemu słowu, na czas wykonuje zlecone prace. Nie pragnie życia towarzyskiego, ale umie znaleźć się wśród ludzi. Ma zamiłowanie do porządku i czystości. Niekiedy oddaje się wątpieniu, ale niestrudzenie szuka prawdy. Największą wartością jest dla niego prawda lub prawo.

Formuła nEAP - cechy charakterystyczne

Jest chłodny i opanowany, uwagę swoją kieruje na życie zewnętrzne, które umie doskonale obserwować. Obdarzony w wybitnym stopniu zmysłem praktycznym, potrafi „sprzedać” swoje wiadomości. Zdolny jest do nauk ścisłych, zwłaszcza eksperymentalnych. Lubi życie towarzyskie, jest grzeczny, dowcipny i uprzejmy, ale bywa również ironiczny i złośliwy. Zna tajemnice kierowania ludźmi, można go nazwać zręcznym dyplomatą. Skłonny jest do oportunizmu i konformizmu, bardzo podatny na wpływy otoczenia. Gotów 
uznać względność norm moralnych, dochodzi nieraz do sceptycyzmu, odznacza się liberalizmem i tolerancyjnością. Daje dowody inicjatywy i wielkiej giętkości umysłu. Spokojny i zrównoważony, nawet w bardzo napiętych sytuacjach. Często nastawiony egoistycznie, bywa nieraz wyrachowany i wykorzystuje innych. Największą wartością jest dla niego powodzenie życiowe, użyteczność.

Formuła EnAS - cechy charakterystyczne

Jest ambitny, ale nie umie urzeczywistnić swych daleko sięgających planów, dlatego poprzestaje na marzeniach. Zadumany, zapatrzony w swoje życie wewnętrzne. Melancholiczny i niezadowolony z siebie, skłonny jest do skrupułów i kompleksów, zwłaszcza kompleksu niższości. Często oskarża samego siebie, a nawet czuje do siebie wstręt. Nieśmiały, drażliwy, przeżywa (choć nie daje tego poznać po sobie) każde słowo niebacznie rzucone przez otoczenie. Pozornie nieczuły i obojętny, pod maską chłodu ukrywa burze wewnętrzne i załamania. Nieufny i podejrzliwy, lęka się wszelkich nowości, zwracając najchętniej myśl ku temu, co minęło. Wciąż szuka przyjaciela, któremu mógłby powierzyć bogactwo swego wewnętrznego życia. Takim powiernikiem niejednokrotnie staje się pamiętnik, chroniony czujnie przed wzrokiem ciekawych. Niezręczny i niepraktyczny, z trudem nawiązuje stosunki z ludźmi, lękając się niezrozumienia i ośmieszenia. Pesymista, nie wierzy we własne siły; często uprzednio rezygnuje z sukcesu, który mógłby zapewne osiągnąć, gdyby miał odrobine ufności do samego siebie. Delikatny w stosunku do innych, umie im okazywać współczucie i otoczyć opieką. Indywidualista, kocha przyrodę i szuka w niej schronienia przed twardością losu. Najwyższą wartością dla niego jest życie wewnętrzne oraz przyjaźń.

Formuła EAS - cechy charakterystyczne

Odznacza się ambicją; umie konsekwentnie urzeczywistniać swoje dalekowzroczne plany. Wielka prężność całej osobowości, skoncentrowana w kierunku określonym przez „główną namiętność”. Charakter władczy, skłonny do panowania zarówno nad sobą, jak nad innymi. Potrafi wyrzec się wszystkiego, co nie prowadzi do umiłowanego celu. Często utożsamia siebie ze sprawą, której służy, lub grupą społeczną, do której należy: z rodziną, państwem, Kościołem. Traktuje więc głęboko i poważnie religię, ojczyznę, obowiązki rodzinne. Doświadcza wciąż nienasyconego głodu wielkości. Wobec 
otoczenia usłużny i ofiarny, ale pod warunkiem, że zostanie uznana wartości jego osoby. Umie ograniczyć swoje potrzeby organiczne, gotów do daleko posuniętego ascetyzmu; potrafi ujarzmiać swoją gwałtowność, chociaż niekiedy wybucha. Wielką energię swej osobowości dyscyplinuje, angażując się do wielkich zadań. Zwykle wszechstronnie uzdolniony, ceni przeszłość, której pragnie być kontynuatorem. Postępuje zwykle uczciwie, ale jest niekiedy skłonny hołdować zasadzie: cel uświęca środki. Najważniejszą dla niego wartością jest zadanie, które ma wykonać.

Formuła nEnAP - cechy charakterystyczne

Jest uczynny, zgodny, tolerancyjny. Da się ukształtować swemu otoczeniu, dlatego mówi się o nim, że ma „dobry charakter”. Niedbały, skłonny do lenistwa, odkłada zlecone czy zamierzone zajęcia. Niepunktualny. Na ogół idzie za tym, co modne, dość zaskakująco przejawia bierny opór. Nie przejmuje się niczym. Często uzdolniony jest do muzyki i sztuki aktorskiej, nieraz obdarzony dobrą pamięcią. Nad wszystko stawia potrzeby organiczne: jedzenie, picie, sen. Ożywia się z częstej „duchowej drzemki” podczas gier i zabaw towarzyskich. Chętnie uprawia gry hazardowe. Lubi wygodne życie w domu rodzinnym, ale nie umie poświęcić się i być ofiarnym. Dość obiektywnie ocenia rzeczywistość. Najwyższą dla niego wartością jest rozrywka, przyjemność.

Formuła nEnAS - cechy charakterystyczne

Bywa zwykle małomówny, zamknięty w sobie i skryty. Nie ma zbyt wielkich aspiracji. Ponury i milczący, rzadko się śmieje. Zwykle uczciwy, prawdomówny, punktualny, odważny. Nudzi się często, brak mu zainteresowań. Zdolny do matematyki i przedmiotów ścisłych, lubi porządek i czystość. Wierny jest zasadom, które mu wpojono, niekiedy przejawia opór, który trudno złamać. Umie być karny i opanowany. Nie lubi nowości, jest raczej konserwatystą. Długo nosi urazy w sercu, niełatwo daje się pogodzić. Odznacza się równym usposobieniem, trzyma się z dala od społeczeństwa. Największą dla niego wartością jest spokój.

Formuła EAP - cechy charakterystyczne

Jest pełen żywotności i energii, działa $\mathrm{z}$ wytężeniem i gorączkowo $\mathrm{w}$ wielu kierunkach. Porywczy i wybuchowy, nieraz grzeszy brakiem umiaru. 
Skłonny do przesady, mierzy siły na zamiary. Wieczny reformator. Usposobienie pogodne, optymistyczne. Z łatwością nawiązuje kontakty towarzyskie i przyjacielskie. Pełen ciepła i ostentacyjnej serdeczności, potrafi przyciągnąć do siebie ludzi. Zwykle dobry mówca, czasem demagog, schlebiający tłumowi, podburzający do buntu. Wierzy w postęp. Szybki, zręczny i zdecydowany. Umie zdobywać, lubi rozkazywać i każdemu dać jakąś robotę do wykonania. Największą wartością jest dla niego działanie.

Odnalazłeś siebie w tych opisach formuł? Może w kilku, a może we wszystkich? To bardzo dobrze! Odnajdą się w nich również strony mediacji. Odnajdzie się każdy. Jesteśmy ludźmi obdarzonymi darami pierwotnymi, ale nade wszystko wolną wolą. Życie jest procesem. Otrzymując od Stwórcy pierwotny temperament, w ciągu swojego życia robimy z nim, co chcemy. Możemy go wykorzystać dla własnego rozwoju lub dla własnej zguby. To my dokonujemy wolnych wyborów, które mogą być trafne lub błędne (chybione). Celem w tym przypadku jest dojrzała osobowość.

Prawo do wolnych wyborów mają też strony mediacji. Mediacja nie jest procesem terapeutycznym, jednak mediator powinien ocenić, czy strony swobodnie korzystają z prawa do wolności - w ramach decyzji dotyczącej przedmiotu powodującego konflikt. Ujawniony w mediacji brak wolności $\mathrm{w}$ decydowaniu stron, nie wchodząc w możliwe powody zniewolenia, jest czynnikiem wskazującym na konieczność przerwania mediacji i próby skierowania stron do odpowiednich specjalistów. Akceptacja cech wrodzonych i rozwój w kierunku osobowości pełnej może być czynnikiem, który pozwoli na dojrzałe regulowanie swoich relacji z otoczeniem. Poprawa w tym zakresie jest możliwa na każdym etapie życia.

Mediator nie dobiera stron, przyjmuje i prowadzi proces na „etapie zastanym” - nie ma wpływu na stan samoświadomości stron. Znając i akceptując siebie, może bardziej świadomie zaakceptować strony. Akceptacja różnorodności, wypływająca z głębokiej samoświadomości, może mieć pozytywny wpływ na bardzo emocjonalny proces mediacji. Wydaje się ona być warunkiem koniecznym wystąpienia postawy bezstronności mediatora wobec stron konfliktu. W tym kontekście każdy krok ku lepszemu poznaniu siebie - potocznie „rozwój osobisty” - jest krokiem w kierunku podnoszenia jakości usługi świadczonej przez mediatora.

Kolejny raz zadajmy sobie pytanie: Jak typologię temperamentów wykorzystać w procesie mediacji? Mam tutaj na myśli każdy podmiot tego procesu: 
zarówno strony stające do mediacji, jak i osobę mediatora, obok którego strony te stają. Zaproponuję spojrzenie z perspektywy podsumowania „najważniejszych wartości" - rozumianych jako główne i przyrodzone motywatory - dla osób obdarowanych danym temperamentem w jego czystej postaci. Pamiętajmy, że jest to jedynie model analityczny i czyste postaci temperamentu w rzeczywistości raczej nie występują lub występują bardzo rzadko.

Tabela 6. Podsumowanie motywatorów w opisie głównych cech osób w typologii wg Le Senne' $a^{14}$

\begin{tabular}{|c|c|}
\hline Formuła temperamentu & $\begin{array}{c}\text { Glówna „wartość” motywująca dzialanie osoby obda- } \\
\text { rowanej danym temperamentem }\end{array}$ \\
\hline EnAP & piękno, rozrywka \\
\hline nEAS & prawda, prawo \\
\hline nEAP & powodzenie życiowe, użyteczność \\
\hline EnAS & życie wewnętrzne, przyjaźń \\
\hline EAS & zadanie do wykonania \\
\hline nEnAP & rozrywka, przyjemność \\
\hline nEnAS & spokój \\
\hline EAP & działanie \\
\hline
\end{tabular}

Wszystkie wymienione w tabeli „wartości” są „dobre”. Czy można być w pełni człowiekiem, nie odnajdując w sobie choć śladu szacunku i uważności dla każdej z nich? Carl Gustav Jung w swoich badaniach zwrócił uwagę, że osobowość składa się z części świadomej i nieświadomej ${ }^{15}$. Dopełnieniem każdej cechy osobowości jest ukryta w podświadomości cecha przeciwnie skierowana. Jeżeli w zachowaniach osoby uwidaczniają się cechy trudne, to ich przeciwieństwa są ukryte w podświadomości i mogą być źródłem dobra. Osobowość pełna to harmonijne połączenie subtelnej i świadomej

14 Opracowanie własne na podstawie: J. Tarnowski, Z tajników naszego "JA”, dz. cyt.

15 Por. J. Strelau, Psychologia temperamentu, dz. cyt., s. 20. 
wrażliwości na wszystkie „wartości” wymienione tabeli 6 . Wychodząc od pierwotnego temperamentu, powinniśmy rozwijać się w kierunku wzmacniania dyspozycji związanych z innymi typami temperamentów, wykorzystując w tym celu wolną wolę i rozum. Natomiast to, co zepchnięte do podświadomości, co najczęściej widzimy jako wadę u innych lub jako przedmiot/ podmiot zazdrości, powinniśmy wyciągać ponad powierzchnię - do świadomych zachowań budujących rozwiniętą i pełną osobowość (por. Łk 8, 16-18). Aby budować osobowość, należy oprzeć się na fundamencie. Temperament - jako najbardziej stały (wg badaczy) element - doskonale się do tego nadaje. Odkrywając fundament, możemy rozpocząć świadomą budowę osobowości w kierunku pełni ukrytej w różnorodności. Przypomnę tutaj dziewiąty temperament sklasyfikowany przez Galena - idealna mieszanka wszystkich składników. Świadome i pogłębione spojrzenie uczestników mediacji na własny temperament - przekształcający się w osobowość - może być podłożem do pozytywnych przeformułowań na kolejnych etapach tego procesu.

\section{Temperament a mediacja}

Strony mediacji to strony konfliktu. Stają się nimi, gdy co najmniej jedna z nich nie potrafi samodzielnie poszukać drogi wyjścia z sytuacji kryzysowej, wywołanej konfliktem lub będącej jego źródłem. Można zatem założyć, że klientem mediatora może być osoba o słabo rozwiniętej osobowości bądź osobowości zbudowanej na „ja fałszywym”" ${ }^{\text {. W }}$ jednym i drugim przypadku sięgnięcie do rdzenia osobowości, czyli do temperamentu, może być wskazaniem kierunku poszukiwań źródeł zrozumienia własnego stanowiska oraz stanowiska strony przeciwnej. Takie spojrzenie w głąb siebie może być pierwszym krokiem w długotrwałym procesie odbudowy osobowości lub konstruowania jej od nowa - na zdrowym fundamencie własnego temperamentu. Atrybuty dobrego mediatora to: cierpliwość Hioba, fizyczna wytrwałość maratończyka, chytrość Machiavellego, umiejętność sondowania osobowości dobrego psychiatry, skóra (odporność) nosorożca, okazywana uczciwość i bezstronność, fundamentalna wiara w ludzkie wartości oraz potencjał wraz ze zdolnością oceny osobistych słabości i mocnych stron, umiejętność analizowania dostępnych opcji w kontraście do tych jedynie pożądanych, odpowiednia energia osobista i ego, a jednocześnie gotowość do

16 Por. M. i M. Gajdowie, Rozwój. Jak współpracować z łaską?, Pro homine, Szczecin 2012, s. 43, 131. 
całkowitego usunięcia się $\mathrm{w}$ cień ${ }^{17} . \mathrm{Z}$ tej charakterystyki widać, że wiedza o temperamentach (fundamencie osobowości) powinna być jednym z narzędzi, którymi mediator posługuje się w swojej praktyce zawodowej. Na kolejnych etapach mediacji znajdziemy możliwość praktycznego zastosowania tych umiejętności. Bez szczegółowej analizy procesu zasygnalizuję jedynie miejsca, w których mediator może, świadomie lub nieświadomie, dotknąć tematyki temperamentu. Świadome wykorzystanie narzędzi diagnostycznych musi być zawsze poprzedzone wewnętrznym przekonaniem mediatora, że jest to odpowiedni moment oraz że strony mediacji posiadają wewnętrzne zasoby niezbędne do ich zaangażowania.

Posłużę się podziałem na sześć etapów, charakterystycznym dla mediacji rodzinnej ${ }^{18}$ :

Wprowadzenie do mediacji. Na tym etapie mediator ma do dyspozycji czas na tzw. monolog mediatora. Jest to narzędzie, które może wciągnąć strony w interakcje - poprzez formułowanie pytań o oczekiwania, wcześniejsze doświadczenia, obawy i lęki. Teoretycznie jest to też miejsce na głębsze poznanie stron - poprzez próbę określenia temperamentu metodami dostosowanymi do sytuacji i zaangażowania stron.

Wstępne wystąpienia stron. Wsłuchiwanie się w historie opowiadane przez strony, zabarwienie emocjonalne ich wypowiedzi oraz formę ekspresji - to czas, w którym mediator może, również przez zadawane pytania, próbować dokonać identyfikacji głównych dyspozycji temperamentu stron. $\mathrm{Na}$ tym etapie będzie to raczej proces intuicyjny, ale opierając się o wybraną metodologię badawczą, można też wykonać notatki do późniejszej analizy. Analiza ta może być dla mediatora czynnikiem obiektywizującym prezentowane stanowiska i wzmacniającym jego bezstronność.

Definiowanie kwestii i ustalanie planu mediacji. $\mathrm{Na}$ tym etapie mediator musi bardzo uważnie dopasować pytania precyzujące stanowiska. Może to robić efektywniej, mając wiedzę o temperamencie stron, formułując m.in. pytania: w kierunku konkretnych zadań do rozwiązania (dla temperamentów wyraźnie aktywnych), w kierunku zaopiekowania emocji (dla temperamentów mocno emocjonalnych), w kierunku szybkich efektów i doraźnych korzyści (dla temperamentów wyraźnie prymalnych), w kierunku

17 Por. A. Gójska, Mediacje rodzinne, dz. cyt., s. 96.

18 Por. A. Gójska, Mediacje rodzinne, dz. cyt., s. 8 o. 
zwracającym uwagę na długofalowe korzyści i ponadczasowe wartości (dla temperamentów wyraźnie sekundalnych).

Poszukiwanie potrzeb i interesów stron. Potrzeby są wspólne dla każdego człowieka. Potrzeby osadzone w pierwotnym temperamencie realizują się w nieskończenie wielu scenariuszach zachowań. Identyfikacja potrzeby pierwotnej jest jakby stanięciem na skale, na której można budować coś trwałego. Zwiększamy wówczas prawdopodobieństwo, że wypracowane porozumienie będzie trwałe. Bardzo ważna jest świadomość mediatora oraz stron, że każda potrzeba jest dobra i nie podlega ocenie moralnej. Istnieje tu podobieństwo do temperamentu, który również jest dobry i nie podlega ocenie moralnej. Wyciągnięcia na powierzchnię obserwacji (analizy, a nie oceny) wymagają metody zaspokajania potrzeb i sposoby stosowane do rozbijania ograniczeń w rozwoju osobowości, które wynikać mogą z pierwotnych dyspozycji temperamentu. Kiedy zbliżymy się do temperamentu stron, łatwiej będzie tę analizę poprowadzić w duchu bezstronności i neutralności.

Poszukiwanie rozwiązań i końcowe negocjacje. Mediator powinien zachęcić strony do poszukiwania kilku opcji rozwiązań możliwych do ułożenia z „puzzli rozsypanych na stole mediacji”. „Puzzle” to np. sytuacja materialna stron, stan ich świadomości, zasoby intelektualne, poziom suwerenności emocjonalnej ${ }^{19}$, poziom odpowiedzialności, temperament, kontekst rodzinny i środowiskowy, wyznawane wartości, rozwój duchowy, doświadczenie, niesione rany, wykształcenie, bieżąca sytuacja gospodarcza, zdrowie, zdolność kredytowa i wiele innych. Przed przystąpieniem do układania obrazu (formułowania dostępnych opcji) musimy „wszystkie puzzle odwrócić na prawą stronę" - to zdecydowanie ułatwi układanie. Kiedy mediator posiada narzędzia pozwalające na przybliżenie do określenia poszczególnych dyspozycji temperamentu, może pomóc stronom mediacji w odsłonięciu również tego elementu układanki. Mediator może:

- dla stron wyraźnie aktywnych - formułować pytania naprowadzające na ten aspekt negocjowanej kwestii, gdzie porozumienie przyniesie konieczny wzrost jej aktywności;

- dla stron wyraźnie nieaktywnych - szukać pytaniami takich kierunków porozumienia, które przy ich realizacji pozwolą na ograniczenie koniecznej aktywności;

19 M.i M. Gajdowie, Rozwój. Jak wspótpracować z łaską?, dz. cyt., s. 82. 
- dla stron emocjonalnych - istotne będzie skierowanie pytaniami uwagi na obszary niewywołujące nadmiernych poruszeń w tej sferze, czyli uspokojenie emocji, co jest warunkiem koniecznym pobudzenia rozumu i obiektywnego namysłu;

- dla stron sekundalnych - pytania mediatora powinny kierować uwagę na długofalowe konsekwencje braku porozumienia, ale również na konieczność pogodzenia się z przeszłością, jak również na skupienie większej uwagi na kwestii konfliktu danych, z których interpretacja wpływa - w sposób trwały - na postawę i stanowisko strony;

- dla stron prymalnych - pytanie o możliwe szybkie efekty porozumienia może zwiększyć dostępne opcje rozwiązań.

Jest to tylko próba podpowiedzi na pytanie, jak kreatywnie zaangażować w tworzenie mediacyjnych pytań i przeformułowań znajomość trzech podstawowych dyspozycji temperamentu. Pamiętajmy jednak, że paleta dyspozycji tworzących formułę temperamentu jest nieograniczona. Uzupełnianie wiedzy mediatora o znajomość kolejnych dyspozycji daje kolejne możliwości pozytywnych przeformułowań. Poza efektem doraźnym w postaci zbliżenia do trwałego porozumienia, uwzględniającego rzeczywiste potrzeby stron, takie ogniskowanie uwagi może zaowocować zapoczątkowaniem osobistego rozwoju stron poprzez zauważanie własnych potrzeb w świetle obiektywnego kryterium, jakim jest temperament - neutralny i niepodlegający ocenie. Jest też szansą spojrzenia na drugą stronę konfliktu w tej samej perspektywie oraz w kontekście jej niepowtarzalnej indywidualności i pięknej odrębności.

Mediator nie powinien naciskać na szybkie porozumienie. Zakładając możliwą ewaluację postawy stron wobec konfliktu, mediator powinien zadbać o czas na refleksję na każdym etapie mediacji. Refleksja jest sprzężeniem zwrotnym dla stron oraz dla mediatora. Jeżeli zachowana zostanie zasada otwartości, wówczas analiza refleksji pomoże wszystkim stronom podjąć decyzję o kontynuacji mediacji lub jej zakończeniu. W pracy stron, pomiędzy spotkaniami, mediator może - przy zachowaniu kryterium świadomej efektywności - zachęcić strony do samodzielnego zagłębienia się w źródła osobowości. Jeżeli np. została zastosowana metoda diagnostyczna określająca dyspozycję temperamentu stron w obszarze biegunowości (M/V), może to dać ciekawe zestawienie z obserwowaną w rzeczywistych negocjacjach postawą stron. Takie cząstkowe zobrazowanie teorii w praktyce może być istotnym czynnikiem otwierającym na kolejne kroki samoobserwacji i rozwoju. 
Praca nad porozumieniem. Ostatni etap mediacji można uzupełnić o ogólną refleksję nad procesem mediacji, co umożliwi zamknięcie procesu mediacji na poziomie relacyjnym i emocjonalnym. Jeżeli w zakończonym procesie zostały zastosowane narzędzia diagnostyczne określające temperamenty stron, wówczas na zakończenie zarówno strony, jak i mediator mogą zweryfikować trafność i przydatność dokonanej diagnozy.

\section{Podsumowanie}

Mediacja, szczególnie rodzinna, próbuje połączyć trwałym porozumieniem strony zazwyczaj pogubione i poranione. Zasadą jest spojrzenie w przyszłość i budowa trwałego porozumienia. Jeżeli zawiodły stosowane dotychczas metody rozwiązywania konfliktów, mediator może ukierunkować patrzenie stron na to, co trwałe i na czym można coś trwałego zbudować. Mediator nie może jednak brać na siebie ciężaru kształtowania osobowości stron, jest jedynie osobą towarzyszącą „tu i teraz”, nic ponad to. Strony muszą wziąć odpowiedzialność za siebie - na siebie. Mogą, ale nie muszą, skorzystać z okazji do spojrzenia w głąb swojej osobowości i dokonania autorefleksji. Mediator natomiast może i powinien przez całe swoje życie kształtować własną osobowość na trwałym fundamencie. W tym procesie może być pomocna wiedza z zakresu typologii temperamentu. Parafrazując przypowieść o talentach (por. Mt 25, 14-30), możemy powiedzieć: osobie, która otrzymała dar kilku dyspozycji temperamentu i rozwinęła je w kolejne - na drodze pracy nad rozwojem własnej osobowości - chwała i zysk. Zachowa to, co otrzymała, i to, co zdobyła. Osobie, która ze swoim temperamentem nie zrobiła nic - została z charakterem opartym tylko o swój temperament - biada i strata. Życie straci, nie kosztując doskonałości smaku owoców, jakie wyrosnąć mogą z postępowania opartego o jej wolne decyzje, podjęte po zaczerpnięciu motywacji ze źródła o optymalnej mieszance wszystkich motywatorów z tabeli 6. Straci ona nawet tę dyspozycję, motywację, „wartość, którą pierwotnie otrzymała. Upadnie na niższy szczebel ewolucji, do stworzeń (organizmów) poruszających się, ale niemających Życia w sobie, do stworzeń, którymi żądzą instynkty. Zrezygnuje w ten sposób z pełni człowieczeństwa. Myślę, że jest to zachęta do rozwoju i bardzo dobra nowina, choć trudna.

Czy jesteśmy teraz bliżej odpowiedzi na pytanie, czy znajomość typologii temperamentu może przysłużyć się w osiągnięciu trwałego porozumienia 
mediacyjnego? Odpowiedzi powinny być różne. Jesteśmy różni. Każdy mediator odpowie sobie na to pytanie wewnątrz swojego ,ja”. Jeżeli mediator jest z natury osobą empatyczną, emocjonalną, ale też trzeźwo sekundalną i aktywną w stopniu gwarantującym autentyczne zaangażowanie w prowadzony proces mediacji, to wiedza ta ugruntuje go w przekonaniu, że jest odpowiednią osobą na odpowiednim miejscu. Jeżeli mediator stwierdzi, że to on wie najlepiej, jak prowadzić mediacje, a temperamenty stron nie mają znaczenia, bo „jak ktoś chce się dogadać to się dogada, a jak nie chce to się nie dogada i już...”, to żadna wiedza mu już nie pomoże - gdy ktoś myśli, że wie wszystko, nie ma już miejsca na jakąkolwiek nową wiedzę. Jeżeli natomiast tak postawione pytanie spowoduje refleksję, apetyt na dalszą eksplorację tematu, chęć do empirycznej weryfikacji tego obszaru wiedzy, zwiększenie bezstronności, uwolnienie od postawy oceny człowieka - bez jego głębszego poznania, umożliwiającego wyodrębnienie jego świadomych wyborów (które możemy i powinniśmy oceniać), to warto było wstępnie przeanalizować ten obszar odsłonięcia rdzenia ludzkiej osobowości.

Mediacja to nie magiczny kapelusz z królikiem gotowym do skoku. Mediacja to raczej „orka na ugorze”. Ale przecież każda urodzajna ziemia była kiedyś ugorem. Czym zatem jest temperament? To ugór - jest czymś do uprawy, miejscem, gdzie kiedyś będzie owoc lub nie. Osobowość? To powstałe w miejscu ugoru urodzajne pole, które daje plon obfity, większy lub mniejszy. Bez ciężkiej pracy nad temperamentem osobowość jest słaba, a owoce kwaśne. Charakter? To aktualne miejsce na skali rozwoju osobowości, w każdym wymiarze człowieczeństwa, gdzie początkiem skali jest otrzymany temperament, a końcem - dojrzała osobowość. O ile osobowość, zmierzająca do dojrzałości, jest wynikiem mniej lub bardziej świadomego rozwoju osoby obdarowanej temperamentem, to charakter jest efektem raczej chaotycznego wzrostu człowieka pod wpływem impulsów zewnętrznych, np. uwarunkowań środowiskowych i kulturowych. Tak rozumiem trzy pojęcia: temperament, osobowość, charakter, często używane wymiennie i bez głębszego namysłu. A mediacja? To doskonały moment, aby strony rozpoczęły bardziej świadomy rozwój osobowości, nie jedyny taki moment w życiu człowieka, ale istotny. 


\section{Bibliografia}

1. Biblia Tysiaclecia, wyd. 4, Wydawnictwo Pallottinum, Poznań 1983.

2. Gajdowie M. i M., Rozwój. Jak współpracować z łaską?, Pro homine Marcin Gajda, Szczecin 2012.

3. Gójska A., Mediacje rodzinne, Wydawnictwa Wydawnictwo Uniwersytetu Warszawskiego, Warszawa 2014.

4. Strelau J., Psychologia temperamentu, Warszawa 2012, Wydawnictwo Naukowe PWN, Warszawa 2012.

5. Tarnowski J., Z tajników naszego „Ja”, Księgarnia św. Wojciecha, Poznań 1987. 